\title{
Critical Strategies to Influence Project Success in Construction Industry
}

\author{
Muhammad Hafizi Danial, Mohd Saidin Misnan
}

\begin{abstract}
This research paper explored the critical strategies to be adopted by organizations that are mainly operating based on project based or project oriented organizational structure. The identified strategies are necessary to compensate the prolong issues embedded in project management practice particularly on misalignment issues between organization and its operational objectives and strategies. Generally, the issues are contributed from several factors such as unclear roles and responsibilities, limited autonomy and accountability, lack of a commercial and customer orientation, and weak of professional capacity. All these factors are extending the gap between the organization strategies and project implementation, and consequently put project success at stake. This study was conducted as an attempt to provide solutions to overcome these long rooted problems found in project implementation. The objectives of this study are to identify the importance factors of top management support to influence on project success, to investigate the relationship between top management support and project success, and to determine the critical top management support that influencing project success. This study was conducted by going through five main steps starting with understanding the nature of the research problems, followed with reviewing and compiling relevant literatures, journals and other sources of secondary data, preparing survey questionnaire form, collecting the data by gathering responses from the targeted samples, analysing the data to generalize the samples' results, before closing with discussion and conclusion. The population of this study are constituted of professional serving in Construction Industry within Johor Bahru area, Malaysia. This study had gathered 100 responses from the targeted respondents through online survey form developed in "Google Form" system. The forms were distributed by forwarding the "link address" to the respondents. The data were analyzed using three different methods which are descriptive mean analysis, correlation analysis and regression analysis for respective research's objectives. The results of this study discovered that organization should prioritize their strategies on three main areas namely financial system, stakeholder management and macro-economic factor. This study also found that organization should adopt all quality of top management supportive behaviours proportionally to ensure the effect of their actions are impactful to influence on project success at three different areas namely future preparation, project efficiency, and business adaptability and success. Organization should adopt
\end{abstract}

Revised Manuscript Received on February 05, 2020.

* Correspondence Author

Muhammad Hafizi Danial*, School of Civil Engineering, Universiti Teknologi Malaysia, Johor Bahru, Malaysia. Email: mhdanial@graduate.utm.my

Mohd Saidin Misnan, Faculty of Built Environment and Surveying, Universiti Teknologi Malaysia, Johor Bahru, Malaysia. Email:

(C) The Authors. Published by Blue Eyes Intelligence Engineering and Sciences Publication (BEIESP). This is an open access article under the CC BY-NC-ND license (http://creativecommons.org/licenses/by-nc-nd/4.0/) b-saidin@utm.my

different strategies when attempting to achieve different criteria of project success. This study's outcomes could provide a useful source of information that may benefit other scholars or companies that are applying project management practice to formulate plan and prioritize line of actions in attempt to improve their organizational performance. This study implies ideas by focusing on optimum numbers of strategies and specific set of actions that are critical to achieve on different kind of project success.

Keywords: Critical success factors, organizational structure and strategies, project success, and project success factors.

\section{INTRODUCTION}

C organizational and project objectives can affect both the project and organizations in terms of money, time, and customer satisfaction [34]. This issue directly affects the project management process including technical, functional or business related events during the project implementation [3]. It is more adverse when handling the project issues in construction industry where all of these issues generally contribute to project deferment and worst to the extent of abandonment [40]. This study was initiated based on common problems found in project management practice with the focus centralized on higher management strategies and its impacts on project success. Top management support is arguably created positive influences to the project success [32]. The support is more necessary against other project's success factors [29]. This study discovers the impactful actions of top management support to be adopted by any project-based or project-oriented organizations as their strategic implementation to pursue for project success.

\section{OBJECTIVES}

The objectives of this study are to identify the importance factors of top management support to influence on project success, to investigate the relationship between top management support and project success, and to determine the critical top management support that influencing project success.

\section{SCOPES}

The scope of this study was focused within Construction Industry located in Johor Bahru area. The samples of this study are constituted of people who serve in project based organization or project oriented organization, and they hold various position from top management to executive level.

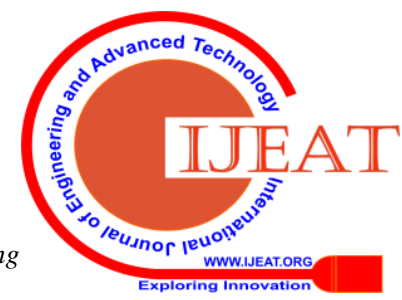




\section{SIGNIFICANT OF STUDY}

This study's outcomes could provide a useful source of information that may benefit other scholars or companies that practicing project management. It could become a basis to formulate plan and prioritize line of actions in attempt to improve their organizational performance. The implied strategies generated from this study are pragmatic as they were set to focus on achieving project success. This study provide ideas by highlighting the critical top management support necessarily to influence on project success. It may facilitate organizations to give more attention on limited numbers of areas that justifiably critical instead of attending to all problems at one time. This idea will improve management efficiency whilst preventing from diversion to other less impactful areas.

\section{DEFINITION OF TERMS}

\section{A. Top Management}

Top management is defined as the highest management level in an organization who control, directing and running an organization [23, 24, 17]. They are accountable and responsible for the organization's survival and growth [17].

\section{B. Project Manager}

Project manager is an individual that assigned by the performing organization to lead a team that is responsible for achieving the project objectives [27]. Project manager's duty are to satisfy the task needs, team needs, and individual needs. In addition, he is a link between the strategy and the team [13].

\section{Project Success}

The fundamental concept to assess the project success is based on the measurement of project success factors [35]. Success criteria is a formulation of specific measurement to determine whether project succeeds or fails [7]. Success criteria is subjective and differ across different kinds of projects, participants, scope of services, project size, and sophistication of the owner related to the design of facilities, technological implications, and other external factors [38].

\section{LITERATURE REVIEW}

\section{A. Instituting an Organizational Structure}

Organization is the foundation of modern social order that forms a structural framework of duties and responsibilities [2]. It is instituted to perform specific actions and collectively collaborate as a whole to meet the organization goals and objectives [2]. A business organisation should be structured in the most effective and efficient way to fully utilise its resources including capital, human resources, expertise and knowledge to achieve its strategic goals [2]. Strategic planning can contribute into positive impacts to the organization performance by generating relevant information, creating a better understanding of the business environment, and reducing uncertainty [33]. The rapid changing of business environment have pushed the organizations' leaders to plan ahead their strategy to curb from ousted in the market [4]. Top management who is the highest management group within an organization hold the accountability to maintain the organizational health and performance [37]. They need to initiate and implant strategies that are adaptable to the market, and continuously monitor and analyze the external environment to look for opportunities, threats, and redirect company strategies when needed [37]. Project is one of the organization's strategic approach to gain revenue and generate profit [18]. Project manager is assigned to lead a team and meet the project objectives [27]. Top management who holds the highest authority at the top of organizational structure plays critical role in ensuring the restrictions of project managers' capacity to be supplemented by providing necessary top management support. Not all top management supports are critical, thus this study provides a clear guide on which top management support strategies to be prioritized in facilitating project manager to achieve project success.

\section{B. Top Management Support Factors to Influence on Project Success}

The importance factors of top management supports are determined based on critical success factors' body of knowledge [42, 32, 8, 30]. The top management support factors are grouped into eight different categories namely legal and political factor, macro-economic factor, financial factor, nature, environmental and social impact factor, bidding and contracting factor, subcontracting and supply chain factor, project factor, and stakeholders factor.

Top management support is one of the elements derived in project success factors or also known as critical success factors [42, 32]. The attempt to measure an element of project success factors against the other elements of the same category will become the basis to measure the importance factors of the needs of top management supports to influence on project success. This attempt is consistent with the preceding scholars' approach $[8,30]$. The investigation to see the interdependence between one element and others under the same category of success factors is a way to identify the cause and effect between one and another [30]. The selection of elements of importance factors of the needs of top management supports will be based on critical success factors associated with the top management support in construction projects. Reference to $[10,41,8,30]$ have established relevant frameworks of critical success factors associated with the construction projects. Their frameworks were carefully reviewed and selected as an attempt to identify what are the important factors of top management support in project management. Reference to [10] has gathered numbers of literatures to come out with a total of 25 factors that lead to project success. The compiled factors are generalized in a single list without classified into difference category. Reference to [41] has identified a total of 46 numbers of variables influencing the success of project management through their extensive reviews on the past literatures before consolidating the factors and came out with the critical success factors' framework. They have grouped the variables into seven different categories based on; (1) project related factors, (2) project planning and management factors, (3) project stakeholders factors (client)

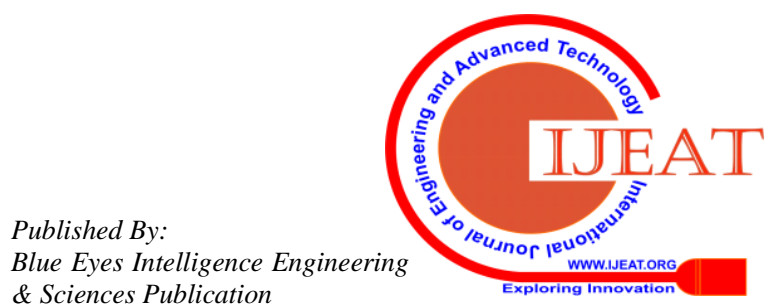


(4) project stakeholders factors (project team leader), (5) project stakeholders factors (consultant), (6) project stakeholders factors (subcontractors), (7) project procurement factors and (8) project external factors.

Reference to [8] has summarized a total of 30 list of project success factors from several scholars associated with key project's key performance indicators (KPIs) namely cost, time, quality, safety, environmental impact and site dispute. Reference to [30] has developed a framework by grouping the critical success factors into five main categories namely project factors, project team factors, organization factors, external environment and sustainability.

\section{The Relationship between Top Management Supports and Project Success}

Top management support demonstrates a direct relationship with the project manager's managerial control and the information system's project performance. Effective managerial control through the appropriate establishment of information and communication management can increase the chances to achieve project success [19]. Top management plays as a moderator to facilitate the project control and influence the success of the project performance [19]. They demonstrate significant relationships with all dimensions of project success dimension namely provide resources, communication, expertise, power and structural arrangement [31]. There are other supported studies that concluded that top management supports including provision of resources, communication management, top management expertise, top management power and structural arrangement show positive relationship with the project success [31]. Table-I shows a balance framework of project success between hard and soft factors. The project success' framework is established using 25 different variables organized in five dimensions. The model contains the three criteria for the iron triangle (dimension 1) plus four additional project success criteria dimensions; (1) project efficiency, (2) organizational benefits, (3) project impact, (4) stakeholder satisfaction, and (5) future potential.

Table- I: Project success regression model by Khan et al. (2013)

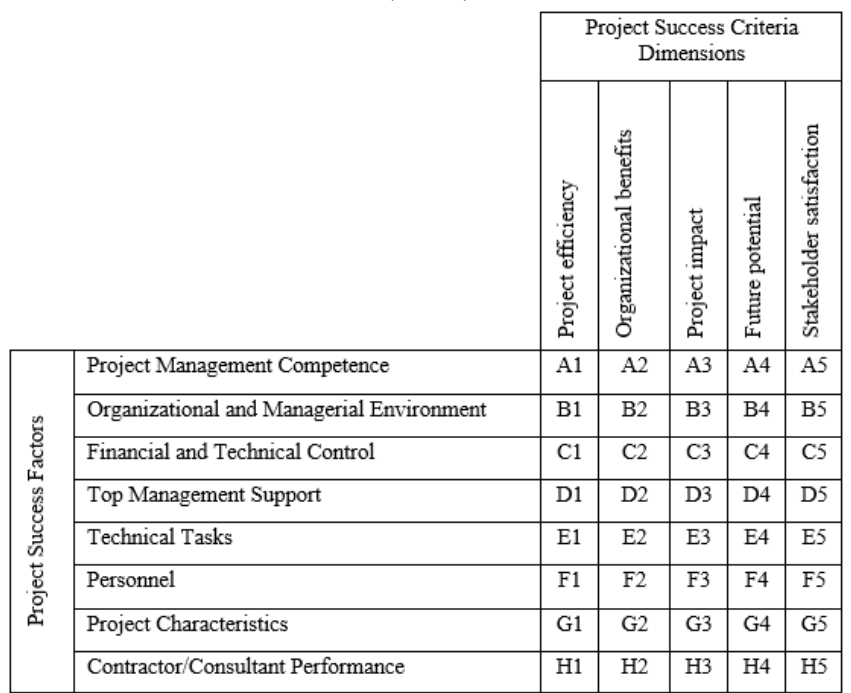

Source: [20]
Table-II shows a four-dimensional framework, where it presents how different types of projects require different success factors, determined by the strategic nature and the short- and long-term project objectives. The dimension of this success' framework was developed by [36].

Table- II: Four dimensions of success

\begin{tabular}{|c|c|c|}
\hline No. & Success Dimension & Measures \\
\hline \multirow[t]{2}{*}{1} & \multirow[t]{2}{*}{ Project Efficiency } & Meeting schedule goal \\
\hline & & Meeting budget goal \\
\hline \multirow[t]{6}{*}{2} & \multirow{6}{*}{$\begin{array}{l}\text { Impact on the } \\
\text { Customer }\end{array}$} & Meeting functional performance \\
\hline & & Meeting technical specifications \\
\hline & & Fulfilling customer needs \\
\hline & & Solving a customer's problem \\
\hline & & The customer is using the product \\
\hline & & Customer satisfaction \\
\hline \multirow[t]{2}{*}{3} & \multirow[t]{2}{*}{ Business Success } & Commercial success \\
\hline & & Creating a large market share \\
\hline \multirow[t]{3}{*}{4} & \multirow{3}{*}{$\begin{array}{l}\text { Preparing for the } \\
\text { future }\end{array}$} & Creating a new market \\
\hline & & Creating a new product line \\
\hline & & Developing a new technology \\
\hline
\end{tabular}

Table-III shows the various past project success' outcomes generated by various preceding scholars including [26, 9, 12, 36, 20, 35].

Table- III: Success dimensions from the literatures

\begin{tabular}{|c|c|c|c|c|c|c|c|c|}
\hline \multirow[b]{2}{*}{ No. } & \multirow[b]{2}{*}{ Project Success Dimensions } & \multicolumn{6}{|c|}{ Scholars } & \\
\hline & & 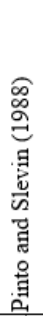 & 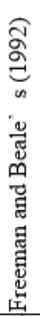 & 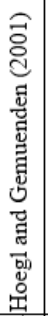 & 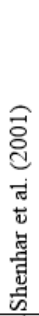 & 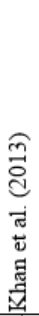 & 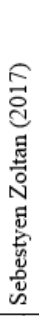 & 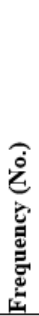 \\
\hline 1 & Project efficiency & $\sqrt{ }$ & $\sqrt{ }$ & $\sqrt{ }$ & $\sqrt{ }$ & $\sqrt{1}$ & $\sqrt{ }$ & 6 \\
\hline 2 & Impact on the project team & & $\sqrt{ }$ & $\sqrt{ }$ & & $\sqrt{1}$ & $\sqrt{ }$ & 4 \\
\hline 3 & Impact on customer & & & & $\sqrt{ }$ & & $\sqrt{ }$ & 2 \\
\hline 4 & Business success & & $\sqrt{ }$ & $\sqrt{ }$ & $\sqrt{ }$ & $\sqrt{ }$ & $\sqrt{ }$ & 5 \\
\hline 5 & Preparing for the future & & $\sqrt{ }$ & $\sqrt{ }$ & $\sqrt{ }$ & $\sqrt{ }$ & & 4 \\
\hline 6 & $\begin{array}{l}\text { Advanced (Ethics, Technology } \\
\text { and Autonomous) }\end{array}$ & & & & & & $\sqrt{ }$ & 1 \\
\hline 7 & Stakeholder satisfaction & & & $\sqrt{ }$ & & $\sqrt{ }$ & $\sqrt{ }$ & 3 \\
\hline
\end{tabular}

\section{The Critical Top Management Supports to Influence on Project Success}

Top management support provides contribution towards the success of quality management [16]. Top management possesses a critical role to uphold the organization's quality objectives across the organization [6]. The project implementation success is depending on several critical success factors and one of it is top management support [21]. Top management supports provide the extent to which top managers demonstrate commitment to protecting nature, drive the firm's environmental strategy, and support its environmental initiatives [22]. Table-IV shows a sample of Top management support's framework generated by [6]. 


\section{Critical Strategies to Influence Project Success in Construction Industry}

Table- IV: Top management support's (TMS)

framework and definitions of support types

\begin{tabular}{|c|c|c|c|c|c|}
\hline \multirow[b]{2}{*}{$\begin{array}{l}\text { Supportive } \\
\text { Behaviour } \\
\text { aimed at }\end{array}$} & \multicolumn{5}{|c|}{ Top Management Support } \\
\hline & $\begin{array}{l}\text { Provision of } \\
\text { financial, material } \\
\text { and human } \\
\text { resources }\end{array}$ & $\begin{array}{l}\text { Structural } \\
\text { arrangements }\end{array}$ & Communication & Expertise & Power \\
\hline $\begin{array}{l}\text { Accomm- } \\
\text { odating the } \\
\text { implement- } \\
\text { tation } \\
\text { project }\end{array}$ & $\begin{array}{l}\text { TM provides the } \\
\text { implementation } \\
\text { project and the team } \\
\text { with adequate } \\
\text { financial, material } \\
\text { and human } \\
\text { resources }\end{array}$ & $\begin{array}{l}\text { TM establishes } \\
\text { and enforces } \\
\text { adequate project } \\
\text { structures. }\end{array}$ & $\begin{array}{l}\text { TM } \\
\text { communicates in } \\
\text { a frequent } \\
\text { manner with } \\
\text { project team and } \\
\text { sells the project } \\
\text { to the rest of the } \\
\text { organization }\end{array}$ & $\begin{array}{l}\text { TM has } \\
\text { relevant ant } \\
\text { expertise and } \\
\text { experience in } \\
\text { project } \\
\text { management. }\end{array}$ & $\begin{array}{l}\text { TM uses its } \\
\text { power to } \\
\text { support the } \\
\text { project and } \\
\text { protect the } \\
\text { project } \\
\text { members. }\end{array}$ \\
\hline $\begin{array}{l}\text { Reshaping } \\
\text { organizat- } \\
\text { ional } \\
\text { context }\end{array}$ & $\begin{array}{l}\text { TM provides } \\
\text { adequate financial, } \\
\text { material and human } \\
\text { resources for } \\
\text { instituting } \\
\text { organizational } \\
\text { changes to facilitate } \\
\text { effective system } \\
\text { implementation }\end{array}$ & $\begin{array}{l}\text { TM adapts the } \\
\text { organization to } \\
\text { the system by } \\
\text { establishing } \\
\text { adapted } \\
\text { structures, } \\
\text { processes and } \\
\text { control systems. }\end{array}$ & $\begin{array}{l}\text { TM } \\
\text { communicates } \\
\text { and explains the } \\
\text { organizational } \\
\text { implications and } \\
\text { organizational } \\
\text { changes } \\
\text { associated with } \\
\text { the } \\
\text { implementation }\end{array}$ & $\begin{array}{l}\text { TM } \\
\text { understands } \\
\text { the organizat- } \\
\text { ional } \\
\text { implications } \\
\text { and changes } \\
\text { related to the } \\
\text { system } \\
\text { implement- } \\
\text { tation. }\end{array}$ & $\begin{array}{l}\text { TM uses its } \\
\text { power for } \\
\text { instituting } \\
\text { organization- } \\
\text { nal changes in } \\
\text { relation to } \\
\text { system } \\
\text { implementa- } \\
\text { tion }\end{array}$ \\
\hline $\begin{array}{l}\text { Adapting } \\
\text { the } \\
\text { information } \\
\text { system to } \\
\text { the } \\
\text { organizat- } \\
\text { ion }\end{array}$ & $\begin{array}{lr}\text { TM } & \text { provides } \\
\text { financial, } & \text { material } \\
\text { and } & \text { human } \\
\text { resources for system } \\
\text { adaptations. }\end{array}$ & $\begin{array}{l}\text { TM establishes } \\
\text { adequate } \\
\text { structures for } \\
\text { system } \\
\text { adaptation. }\end{array}$ & $\begin{array}{l}\text { TM } \\
\text { communicates } \\
\text { and discusses } \\
\text { possible system } \\
\text { changes with } \\
\text { those involved. }\end{array}$ & $\begin{array}{l}\text { TM } \\
\text { understands } \\
\text { the necessary } \\
\text { system } \\
\text { adaptation-ns. }\end{array}$ & $\begin{array}{l}\text { TM uses } \\
\text { power to } \\
\text { facilitate and } \\
\text { enforce } \\
\text { necessary } \\
\text { system } \\
\text { changes. }\end{array}$ \\
\hline $\begin{array}{l}\text { Dealing } \\
\text { with } \\
\text { stakehold- } \\
\text { ers }\end{array}$ & $\begin{array}{lr}\text { TM } & \text { provides } \\
\text { financial, } & \text { material } \\
\text { and } & \text { human } \\
\text { resources } & \text { to } \\
\text { promote } & \text { a } \\
\text { supportive } & \\
\text { stakeholder } & \\
\text { environment } & \\
\end{array}$ & $\begin{array}{l}\text { TM adapts the } \\
\text { organization to } \\
\text { strengthen } \\
\text { stakeholder } \\
\text { support. }\end{array}$ & $\begin{array}{l}\text { TM } \\
\text { communicates } \\
\text { and discusses } \\
\text { the project's } \\
\text { implications } \\
\text { with various } \\
\text { stakeholder } \\
\text { groups. }\end{array}$ & $\begin{array}{l}\text { TM } \\
\text { understands } \\
\text { the power and } \\
\text { interests of } \\
\text { stakeholders } \\
\text { around the } \\
\text { project. the }\end{array}$ & $\begin{array}{l}\text { TM uses } \\
\text { power to } \\
\text { influence } \\
\text { roles and } \\
\text { positions of } \\
\text { stakeholders. }\end{array}$ \\
\hline
\end{tabular}

Source: [6]

Top management support is essential for allocation of resources [5]. Top management provides adequate financial, material, and human resources for implementation of the project, instituting organizational change, achieving business success, an adaptation of the new system, and encouraging environment to the stakeholder for successful completion of the project [6].

\section{RESEARCH METHODOLOGY}

This study was conducted by following step by step procedure as shown in the following Fig. 1 encompassed of five main processes which are; (1) problems identification, (2) prepare literature reviews relevant to scope of studies, (3) data collection, (4) data analysis, and (5) discussion and conclusion of the findings.

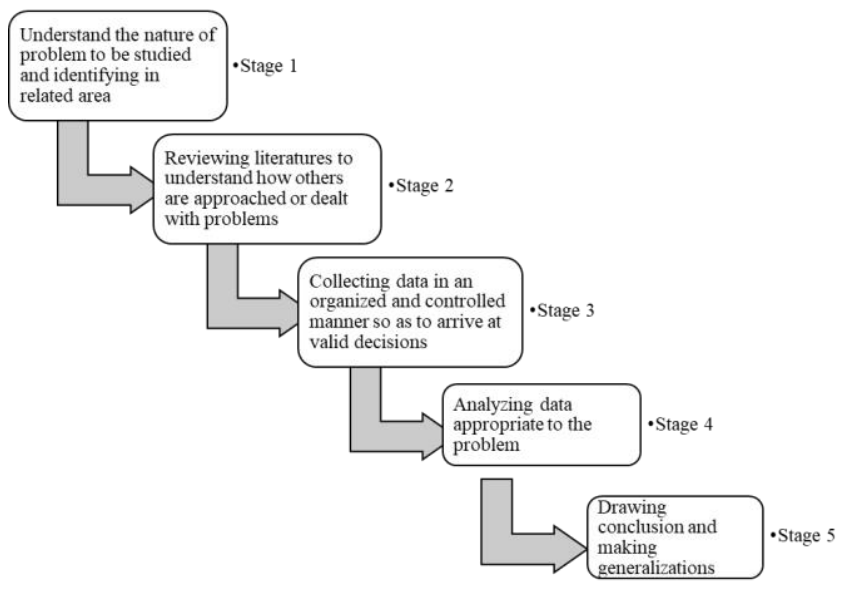

Fig. 1.Systematic research process.

This study was started with the deliberation of problems recognized in project management practice. It followed with a literature review process which helped to deeply understand on the topic of this study whilst tailoring the body of knowledge of top management support and project success, with the study's objectives. Suitable preceding frameworks and parameters were properly reviewed and compiled in the literatures as the basis to design the survey form, which was the main instrument of this study to collect data. The suitable research model was chosen as the study basis by matching up with the study's objectives. The model is presented in Fig. 2.

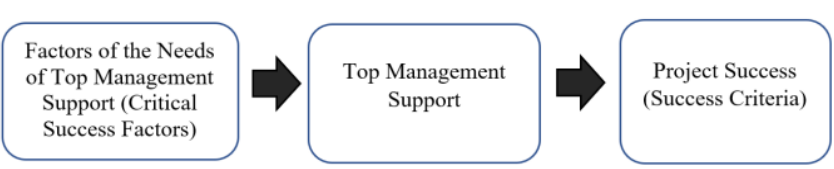

Fig. 2.Research framework.

The samples of this study was focusing the findings within construction industry in Johor Bahru area only. The respondents were selected from professionals group serving in project-based or project-oriented organizations, and they hold various position from top management to executive level. This study solely employed quantitative research approach with the attention was given on investigation of necessary findings based on top management support and project successes' topics. The collected data were analyzed using three different methods namely descriptive-mean analysis, correlation analysis and regression analysis to produce results and generalize the findings. Those outcomes were then discussed in a systematic way by highlighting the similarity, differences or any unique pattern emerged contrary to the literatures. The discussions were the main inputs to address to each study's objective. The objectives were composed and concluded based on the elaborated discussion and findings. The final part of this study highlighted the study's limitation and proposed future recommendations.

\section{RESULTS AND DISCUSSION}

\section{A. Research Objective 1: The Importance Factors of Top Management Support to Influence Project success}

Fig. 3 shows the importance of top management support (TMS) factors across eight different categories. The results show that the "very high important" factors of TMS are; (1) Financial, (2) Stakeholders, and (3) Macro-Economic. The rest mean values of top management support factors are classified under "high important" factors only. The top three highest factors are closely connected with top management roles and responsibility in organization. Those factors including financial, stakeholders and macro-economic are the fundamental input of organizational design and strategic plan. 


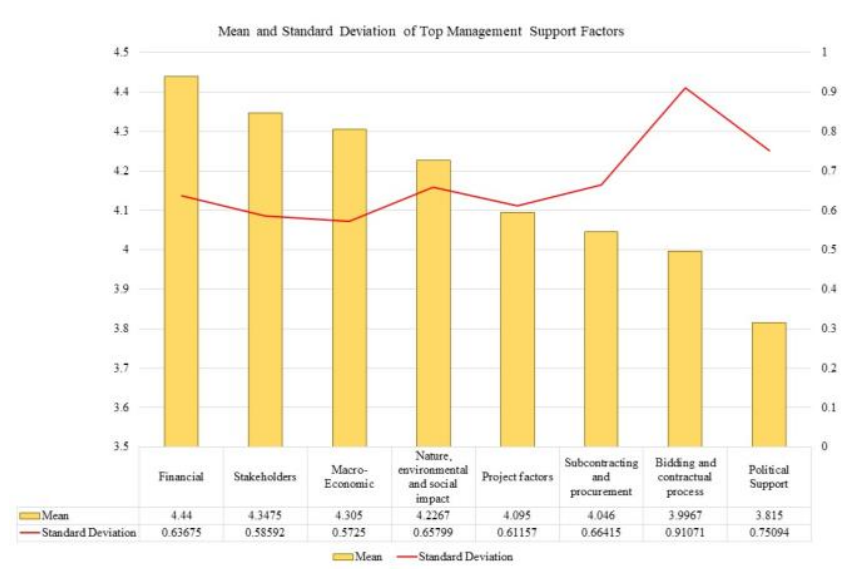

Fig. 3.Mean and standard deviation of top management support factors.

The organizational strategic decisions and plans are highly relying on the rapid changing of business environment which pushing the organizations' leaders to plan ahead their strategy to curb from ousted in the market. Financial factor, stakeholders' factor and macro-economic factor are the key determinant of business decisions in attempt to deal with the market and environment. Business leaders have to be innovative in exploring new market and to be adaptable with the changing environment.

On the other hand, the bottom three of lowest mean values of top management support factors are political support, bidding and contractual process, and subcontracting and procurement. The two out of three factors are the internal process of an organization which predominantly under the responsible of the strategic implementer namely the middle management and first line managers. Thus, it might be the reason why most of the respondents tended to prioritize the importance top management support factors on other area. Those two factors are closely connected with middle management and first line managers as the factors are part of the organizational primary activities instead of strategic decisions or planning. Middle management hold critical roles in materializing the organizational goals by consistently coordinating activities between the top management's strategic planning and the implementation by the first line managers' operational management. Even though they are positioned in the middle between top management and first line managers, they still have to work closely with the first line managers to implement the strategic actions and reporting the performance to the top management. These two main organizational activities are the departmental focus tasks, thus they have less interaction with the top management's key strategic planning and decision making as these tasks are directly under the responsible of functional managers.

The most lowest mean value which is belong to political and legal factor reflects how a business environment have less political and legal impact to affect the project success. This is truth and applicable for political environment in Malaysian context only as $97 \%$ of the respondents are local Malaysian. Even though political-economy influences the level of economic development of a nation and has direct impact on the business activities, but different countries are set with different political nature and economic system. Most business investors around the world are highly cautious in selecting a country for international investment. They are only favour to invest in countries with a favourable business setting that can protect their property rights including stability of government through democratic forms, market-based reforms, and adoption of effective legal system. Political and legal system in Malaysia are stable and well organized, thus encourages for more international investment to foster our economic development. This might become one of the reason why most respondents didn't put their priority on political and legal factor as "very important factor" to influence project success.

\section{B. Research Objective 2: Relationship between Top Management Support Behaviors and Project Success}

Table-V shows each relationship between top management support's variables and project success' variables. The results show that all variables are positively correlated where the top five highest correlation values are between; (1) "overall top management support" and "overall project success", (2) "overall top management support" and "future preparation", (3) "overall top management support" and "project efficiency", (4) "overall top management support" and "business adaptability and success", and (5) "communication management" and "project efficiency".

\section{Table- V: The correlation value between top management support behaviours and project success criteria}

\begin{tabular}{|c|c|c|c|c|c|c|c|c|}
\hline \multirow[b]{2}{*}{ No. } & \multirow[b]{2}{*}{$\begin{array}{c}\text { Top } \\
\text { Management } \\
\text { Support } \\
\text { Behaviours }\end{array}$} & \multirow[b]{2}{*}{$\begin{array}{c}\text { Measurement } \\
\text { Indicator }\end{array}$} & \multirow{2}{*}{ 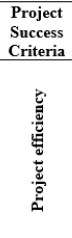 } & \multirow[b]{2}{*}{$\begin{array}{l}\text { Measurement } \\
\text { Indicator }\end{array}$} & \multicolumn{3}{|c|}{ Project Success Criteria } & \multirow[b]{2}{*}{ 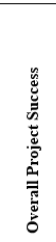 } \\
\hline & & & & & 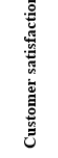 & 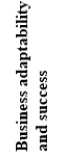 & 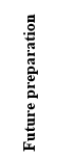 & \\
\hline \multirow[b]{2}{*}{1} & \multirow{2}{*}{$\begin{array}{l}\text { Provision of } \\
\text { Resources }\end{array}$} & $\begin{array}{l}\text { Spearman } \\
\text { Coefficient }\end{array}$ & $0.649^{b}$ & $\begin{array}{c}\text { Person } \\
\text { Coefficient }\end{array}$ & $0.459^{c}$ & $0.613^{b}$ & $0.663^{\mathrm{b}}$ & $0.643^{b}$ \\
\hline & & $\begin{array}{l}\text { Significant } \\
\text { (2-tailed) }\end{array}$ & .000 & $\begin{array}{l}\text { Significant } \\
\text { (2-tailed) }\end{array}$ & .000 & .000 & .000 & .000 \\
\hline \multirow{2}{*}{2} & \multirow{2}{*}{\begin{tabular}{|l|} 
Organization \\
Structural \\
Arrangement \\
\end{tabular}} & $\begin{array}{c}\text { Spearman } \\
\text { Coefficient }\end{array}$ & $0.651^{b}$ & $\begin{array}{c}\text { Person } \\
\text { Coefficient }\end{array}$ & $0.542^{b}$ & $0.620^{b}$ & $0.684^{\mathrm{b}}$ & $0.664^{b}$ \\
\hline & & Significant & .000 & Significant & .000 & .000 & .000 & .000 \\
\hline \multirow{2}{*}{3} & \multirow{2}{*}{\begin{tabular}{|l|}
$\begin{array}{l}\text { Communication } \\
\text { management }\end{array}$ \\
\end{tabular}} & $\begin{array}{c}\text { Spearman } \\
\text { Coefficient }\end{array}$ & $0.707^{2}$ & $\begin{array}{c}\text { Person } \\
\text { Coefficient }\end{array}$ & $0.467 \mathrm{c}^{\mathrm{c}}$ & $0.655^{\mathrm{b}}$ & $0.632^{b}$ & $0.656^{\circ}$ \\
\hline & & Significant & .000 & Significant & .000 & .000 & .000 & .000 \\
\hline \multirow{2}{*}{4} & \multirow{2}{*}{\begin{tabular}{|l|}
$\begin{array}{l}\text { Top } \\
\text { management } \\
\text { expertise }\end{array}$ \\
\end{tabular}} & $\begin{array}{c}\text { Spearman } \\
\text { Coefficient }\end{array}$ & $0.595^{b}$ & $\begin{array}{c}\text { Person } \\
\text { Coefficient }\end{array}$ & $0.388^{\circ}$ & $0.577^{b}$ & $0.589^{\circ}$ & $0.575^{b}$ \\
\hline & & Significant & .000 & Significant & .000 & .000 & .000 & .000 \\
\hline \multirow{2}{*}{5} & \multirow{2}{*}{\begin{tabular}{|l|}
$\begin{array}{l}\text { Top } \\
\text { management } \\
\text { power }\end{array}$ \\
\end{tabular}} & $\begin{array}{c}\text { Spearman } \\
\text { Coefficient }\end{array}$ & $0.558^{b}$ & $\begin{array}{c}\text { Person } \\
\text { Coefficient }\end{array}$ & $0.498^{\mathrm{c}}$ & $0.596^{\mathrm{b}}$ & $0.605^{b}$ & $0.637^{\mathrm{b}}$ \\
\hline & & Significant & .000 & Significant & .000 & .000 & .000 & .000 \\
\hline \multirow[t]{2}{*}{6} & \multirow{2}{*}{$\begin{array}{l}\text { Overall Top } \\
\text { Management } \\
\text { Support }\end{array}$} & $\begin{array}{c}\text { Spearman } \\
\text { Coefficient }\end{array}$ & $0.726^{\mathrm{a}}$ & $\begin{array}{c}\text { Person } \\
\text { Coefficient }\end{array}$ & $0.550^{\mathrm{b}}$ & $0.714^{b}$ & $0.738^{2}$ & $0.741^{2}$ \\
\hline & & Significant & .000 & Significant & .000 & .000 & .000 & .000 \\
\hline
\end{tabular}

${ }^{a}$ Correlation is significant at the 0.01 level (2-tailed)- very strong correlation. ${ }^{\mathrm{b} C}$ Correlation is significant at the 0.01 level (2-tailed) -strong correlation.

'Correlation is significant at the 0.01 level (2-tailed)- moderately strong correlation.

The highest correlation value was measured at 0.741 for relationship between "overall top management support" and "overall project success". This relationship implies how importance is to have a combination of "overall top management support behaviours" to highly impact on "total project success". The combination of various supports have to be exercised in a balance way to exploit the dynamic potential of each behaviours. The balance supports are produced by well distribution of focus across all areas of support behaviours without abandon or bias on any specific behaviours namely; (1) provision of organizational resources, (2) sustain effectiveness of organizational structure, (3) establish effective communication management across the organization and stakeholders, 
(4) improve level of expertise through self-development or continuous learning process to have better control on organizational implementation and strategic decisions, and (5) lastly to appropriately use the power by adopting different forms of power to affect the behaviour and performance of their employees.

The balanced behaviours of top management support are highly sought to impact on individual project success criteria namely "business success", "project efficiency" and "future preparation" with each correlation value stood at $0.714,0.726$ and 0.738 respectively. "Business success" and "Future Preparation" success criteria are closely connected with the top management roles and responsibility including to plan, resolve problem, and make decisions to make the business more successful. They hold high degree of accountability to maintain the organizational health and performance. The project success are highly depending on clear setting of project objectives and performance targets to effectively direct all the activities to accomplish the desired goals.

Most respondents agreed that top management are the key determinant to adapt the organization with the changing market and economic environment. The successful of an organization is depending on how good the top management preparing the organization for future adaption as they are the driver to initiate the strategic decisions by considering various opportunities and threats prior to redirect the strategies when needed.

"Project efficiency" which stands in between "business success" and "future preparation" is one of the top five very strong relationship. The "very strong relationship" between "overall top management" and "project efficiency" is not necessarily meant that the participation of top management in project implementation is highly important, but it indicates the urgency of top management support to customize the business process and strategies that tailor with specific project requirement to improve its execution and directly impact on "project efficiency". This attempt is much more effective and provides fast solution instead of restructuring the organizational process and strategies at big scale to suit with never ending requirement of different kind of projects. This finding is consistent with a study done by [36]. The other "very strong relationship" type is between "communication management" and "project efficiency". An effective communication process can eliminate any misunderstanding across the organizations. Thus, top management support particularly on "communication management" is highly important by ensuring the effective establishment of communication mechanisms to sustain organization's performance, productivity and profitability. In project level, top management need to be fed with constant information flow to immediately recognize any difficulty and challenges that require their immediate attention with related to the business process and policy to improve the "project efficiency". "Communication management" is the critical intermediary to link the project implementation and organizational strategies as a way to complement the project needs and tailor with external changes such as economic condition and market fluctuation as proved by [25].

On the other hand, there are also other contradict findings all of the bottom five of correlation values are associated with "customer satisfaction". The results of the lowest correlation value scores show that four correlation values out of five demonstrate moderate relationship between various demonstrated by the correlation values score. From Table- V,

individual "top management support behaviours" and "customer satisfaction" which are; (1) "top management expertise" at $0.388,(2)$ "provision of resources" at 0.459, (3) "communication management" at 0.467 , and (4) "top management power" at 0.498 .

The other behaviour which is "structural arrangement" demonstrates strong relationship with "customer satisfaction" with correlation coefficient value stands at 0.542. These findings suggest that the top management support is not critically needed to influence on "customer satisfaction". Customer satisfaction is highly influence by the way they received the services provided by the organization. The functional or services unit are the responsible department to directly handle and interact with the customer, and the extent of their behaviours will influence customer perception and perspectives of the received service. This means that top management involvement in the customer interaction process may not be visible as they are not placed at the frontline to serve the customer. This might be the reason why most respondents' votes are not reflecting the close connection between "top management support" and "customer satisfaction".

The respondents' feedbacks show that "top management support behaviours" in "structural arrangement" demonstrates the highest correlation value among all other behaviours to influence on "customer satisfaction". This finding implies that top management should emphasis the efforts to meet customer satisfaction by focusing the task at highest organizational level to develop a well-structured organization that can serve the customer effectively. The strategic planning includes creating specialized functional department that can deal and handle the customer needs continuously whilst organizing a supportive customer service unit to facilitate the continuous interaction with the existing client as a way to retain the customers' loyalty. This will increase the organizational efficiency whilst improving the customer satisfaction index.

\section{Research Objective 3: Critical Top Management Supports that Influencing the Project Success}

Table-VI shows the results of regression coefficient values between top management support's variables and project success' variables. The results are presented in graphical form to assess the criticality of top management supports to impact on project success as shown in Fig. 4.

Table- VI: The critical top management support

\begin{tabular}{|c|c|c|c|c|c|c|}
\hline \multirow[b]{2}{*}{ No. } & \multirow[b]{2}{*}{ Variable } & \multirow[b]{2}{*}{$\begin{array}{l}\text { Measurement } \\
\text { Indicator }\end{array}$} & \multicolumn{4}{|c|}{ Project Success Criteria } \\
\hline & & & 莺 & 竎 & 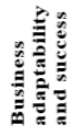 & 总 \\
\hline \multirow{2}{*}{1} & \multirow{2}{*}{ Provision of Resources } & Regression Coeff., $\mathrm{R}^{2}$ & 0.278 & 0.211 & 0.376 & 0.440 \\
\hline & & Significant & .000 & .000 & .000 & .000 \\
\hline \multirow{2}{*}{2} & \multirow{2}{*}{$\begin{array}{l}\text { Organization Structural } \\
\text { Arrangement }\end{array}$} & Regression Coeff., $\mathrm{R}^{2}$ & 0.233 & 0.294 & $0.406^{2}$ & 0.468 \\
\hline & & Significant & .000 & .000 & .000 & .000 \\
\hline \multirow{2}{*}{3} & \multirow{2}{*}{$\begin{array}{l}\text { Communication } \\
\text { management }\end{array}$} & Regression Coeff., $\mathrm{R}^{2}$ & 0.306 & 0.218 & $0.441^{2}$ & 0.400 \\
\hline & & Significant & .000 & .000 & .000 & .000 \\
\hline \multirow{2}{*}{4} & \multirow{2}{*}{$\begin{array}{l}\text { Top management } \\
\text { expertise }\end{array}$} & Regression Coeff., $\mathrm{R}^{2}$ & 0.222 & 0.151 & 0.333 & 0.347 \\
\hline & & Significant & .000 & .000 & .000 & .000 \\
\hline \multirow{2}{*}{5} & \multirow{2}{*}{$\begin{array}{l}\text { Top management } \\
\text { power }\end{array}$} & Regression Coeff., $\mathrm{R}^{2}$ & 0.285 & 0.248 & 0.355 & $0.438^{\mathrm{a}}$ \\
\hline & & Significant & .000 & .000 & .000 & .000 \\
\hline
\end{tabular}


Fig. 4 presents a clearer graphical information to assess the criticality of top management support in hierarchical order. This way will facilitate top management in prioritizing their strategic participation either directly or indirectly in project implementation to produce most impactful actions to meet project goals and extend the goals' achievement to affect organizational success at large. Based on the plotted regression results in the radar chart, the pattern of multiple lines are mostly inclined at two different project success criteria which are; (1) future preparation, and (2) business adaptability and success. This finding provides a clear guide to the organization and top management particularly to concentrate on alignment of their strategic plan and actions that suffice project requirement to achieve project success. The key point here is the alignment of organizational strategic actions and strategic implementation by identifying what to be done if they want to be more successful in the future.

Various Top Management Supports' impacts on Project Success

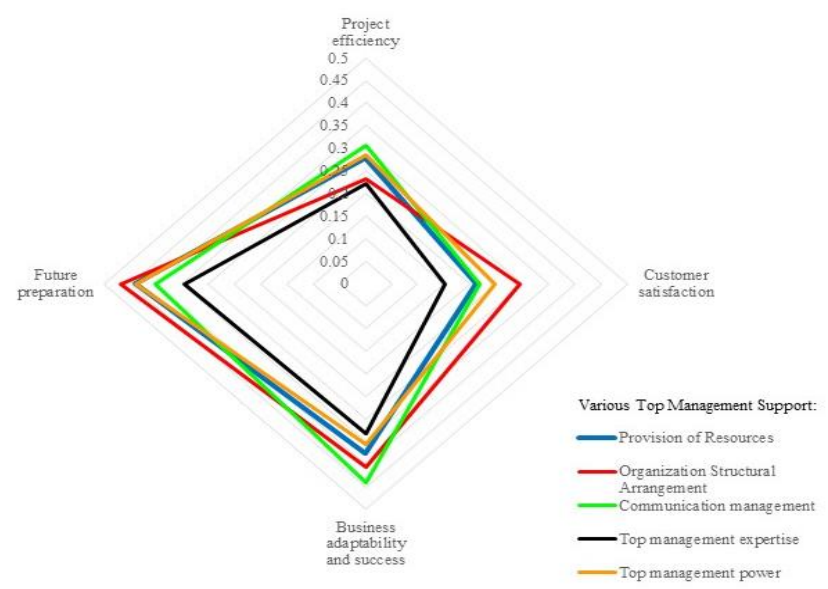

Fig. 4.Various top management support's impact on project success.

Refer to the above chart, the graphical trend lines which are converged at two different project success criteria imply the urgency to deeply explore on these two continuums of success definition, and appropriately identify (1) what are the suitable goals to be set in meeting project success, and (2) how to achieve the desired goals. These two settings are critical as they are associated with the strategic approach to enhance the strategic participation of top management to improve on "business adaptability and success", and "future preparation". This is aligned with the literatures' findings by $[43,15]$, where strategic management involves continuous cycles of analysing and improving the organizational fundamental activities to align with strategies.

Organizations need to constantly adjust the strategic approaches to tailor with the market and environment when needed as a way to sustain "business adaptability and success", where it reflects the similar findings produced by [15]. The ability to respond to the changes will create gap and distance themselves from the flounder organizations.

The second area of critical success is "future preparation". Future preparation is part of organizational strategic management to forecast and identify the probable opportunities and threats bring by the environment changes. Uncertain environment can offer opportunities and threats which may impact the project implementation in different way depending on how the organization deal with the changes. Organizations need to constantly change their established process and true course of action by adapting to the market and business needs, and similar outcome was suggested by [1]. Top management need to adopt changes as a way to seize for opportunity. Therefore, they need to innovate new capabilities by gaining experience and develop the expertise through the undertaking projects. This is a way to prepare themselves by making necessary changes in developing new capabilities to create competitive advantage.

The competitive advantage will facilitate the organization to grow in other business segment in the future. The changes in organizational designs and strategies offer wide range of opportunities to shape the organization into a better enterprise in the future. The change will facilitate the organization to prepare for the worst as the established business plan not necessarily work at all time, and consistent with the study's findings by [1]. Organizations have to consider various aspects in managing organizational change by considering internal and external factors including local, national, and international environment events and the changing trends. They have to determine the probability of future scenarios, the impacts, and the necessary preparation to mitigate the impacts, or seize the opportunities when others see them as threats. This principle will shape an organization to be adaptable to change and prepare the organization to be fitted in undertaking any future project.

\section{CONCLUSIONS}

The first objective of this study is to identify the importance factors of the needs of top management support that influencing project success. Based on the analyzed data, the results indicate that the "very high important" top management support factors are; (1) Financial, (2) Stakeholders, and (3) Macro-Economic. All of these factors are closely associated with internal and external project's opportunities and threats. A project manager may have limitation to access to all of these factors due to limited of authority and access to attend to certain complex matters. The complex matters may include restructuring of financial system and policies to accommodate project's requirement, engagement with high power stakeholders where commonly beyond the project manager's reach such as to influence on investors decision to invest or fund projects, to negotiate with local regulators to facilitate the project implementation that may not in favour of country's laws, and to set reasonable project goals and align with effective organizational strategic plan that are adaptable with economic and environment changes. The second objective of this study is to investigate the relationship between top management support as independent variables and project success as dependent variable. Based on the analyzed data, the results indicate that the "very strong relationship" between these two variables relationship are; (1) "overall top management support" and "future preparation", (2) "overall top management support" and "project efficiency", and (3) "overall top management support" and "business adaptability and success". 


\section{Critical Strategies to Influence Project Success in Construction Industry}

All of these correlation values were not specifying on any individual behaviors of top management support, thus this findings conclude that a combination of overall top management support behaviors are very important to give more impactful results of project success. The combination of top management supports carry dynamic potential from each behaviors to synergize a higher impact relative to individual behaviour.

The third objective of this study is to determine the critical strategies of top management supports that carry high impact actions to influence on project success. Based on the regression analysis, the results indicate that top management should emphasize on prioritizing the specific strategic support based on unique project success criteria. The first part of the analysis suggest that top management should adopt a strategic approach particularly in developing an effective communication management system that can improve the information exchange effectiveness between project team and top management group. The second part of the analysis concluded that top management should sustain business adaptability and success by focusing on two main strategies namely organizational arrangement and communication management. The last part of the analysis suggests that top management should also emphasize on achieving success in future preparation to sustain the current business strategic implementation and be adapted with the market and environment changes. This success can be achieved by building new capabilities through implementation of new project that bring values and open opportunities to organization in developing new capabilities. The project may become as one of the organizational strategy to build up new skills and knowledge across the organization by applying "on job training" concept. This approach will demand higher top management support including restructuring organizational system to facilitate project efficiency, provision of sufficient organizational resources, adopting necessary top management powers to influence employees' behaviors in supporting organizational new endeavors that demands more efforts and higher motivation of employees, and improving communication mechanism and system to increase project efficiency by applying the latest industrial revolution 4.0 (IR 4.0).

\section{RECOMMENDATIONS}

This study did not provide detail strategic approach on finance, stakeholder management and macro-economic factors, thus a potential study can be executed to refine the subject of focus on these three critical areas. Scholars who may have the same interest to study the problems associated with top management support and project success can also consider to carry out study in other different industries but related to project management practice such as logistics and transportation industry, information technology industry, food industry, automotive industry, research and development field, manufacturing industry and many more. The study also can be set at different locations, which may generate discrepancies of findings, henceforth will create another extension of knowledge in top management support and project success literatures.

\section{ACKNOWLEDGMENT}

We thank to Universiti Teknologi Malaysia staff, colleagues, friends and families for the advice, supports and encouragement throughout this research completion.

\section{REFERENCES}

1. Abe Harraf, Isaac Wanasika, Kaylynn Tate and Kaitlyn Talbott (2015) “Organizational agility", Journal of Applied Business Research, 31(2), 675-686.

2. Aldrich, Howard E. and Ruef, Martin (2006) Organizations evolving. 2nd edition. Thousand Oaks, California: Sage Publications.

3. Amr Mossalam. (2017) "Projects' issues management", Housing and Building National Research Center, 14, 400-407.

4. Arthur Poscha and Christian Garaus (2019) "Boon or curse? a contingent view on the relationship between strategic planning and organizational ambidexterity", Long Range Planning, https://doi.org/10.1016/j.lrp.2019.03.004, to be published.

5. Avolio, B. J., Bass, B. M., \& Jung, D. I. (1999) "Re-examining the components of transformational and transactional leadership using the multifactor leadership questionnaire", Journal of Occupational \& Organizational Psychology, 72, 441-462.

6. Boonstra, Albert (2013) "How do top managers support strategic information system projects and why do they sometimes withhold this support?", Journal International Journal of Project Management, 31 (4), 498-512.

7. Cooke-Davies, T. (2017) "The real success factors on projects", International Journal of Project Management, 20 (3), 185-190.

8. Das, Debadyuti and Ngacho, Christopher (2017) "Critical success factors influencing the performance of development projects: an empirical study of Constituency Development Fund projects in Kenya", IIMB Management Review, 29, 276-293.

9. Freeman, M. \& Beale, P. (1992) "Measuring project success", Project Management Journal, 23(1), 8-17.

10. Gunduz, Murat and Ahmad Mohammed Ali Yahya (2015) “Analysis of project success factors in construction industry", Technological and Economic Development of Economy, 24(1), 67-80.

11. Henderson, J.C., Lee, S. (1992) "Managing I/S design teams: a control theories perspective", Management Science, 38(6), 757-777.

12. Hoegl, Martin and Gemuenden, Hans Georg (2001) "Teamwork quality and the success of innovative projects: a theoretical concept and empirical evidence", Organization Science, 12(4), 435-449.

13. Ika, Lavagnon A. and Saint-Macary, Jan (2012) "The project planning myth in international development", International Journal of Managing Projects in Business, 5(3), 42- 439.

14. Jackson, C.M., Chow, S. and Leitch, R.A. (1997) "Toward an understanding of the behavioral intention to use an information system", Decision Science, 28 (2), 357-389.

15. James L. Gibson, John M. Ivancevich, James H. Donnelly, Jr. and Robert Konopaske (2012) Organizations: behavior, structure, processes. 14th edition, New York: McGraw-Hill.

16. Javed, Samia (2015) "Impact of Top Management Commitment on Quality Management", International Journal of Scientific and Research Publications, 5(8), 1-5.

17. Johnson S. and Rashmi K., (2016) "Top level manager: skills, functions, tasks, approaches, responsibilities and roles", Asian Journal of Management Research, 7 (2), 170-178.

18. J. Rodney Turner (2018) "The management of the project-based organization: a personal reflection", International Journal of Project Management, 36, 231-240.

19. Kanwal, Narmeen, Muhammad Shahnawaz Zafar and Bashir, Sajid (2017) "The combined effects of managerial control, resource commitment, and top management support on the successful delivery of information systems projects", International Journal of Project Management, 35, 1459-1465.

20. Khan, K., Turner, J.R. and Maqsood, T. (2013) Factors that Influence the Success of Public Sector Projects in Pakistan. Proceedings of IRNOP 2013 Conference. 17-19 June. Oslo, Norway: BI Norwegian Business School. 
21. Li Cai, Qing Li and Xiaoyu Yu (2013) "Effects of top management team heterogeneous background and behavioural attributes on the performance of new ventures", Systems Research and Behavioural Science, 30 (3), 354-366.

22. Liang Zhang, Matthew K. O. Lee, Zhe Zhang and Probir Banerjee (2003) Critical Success Factors Resource Planning Systems Implementation Success in China. 36th Annual Hawaii International Conference on System Sciences. January. Proceedings of the IEEE. Nick Van Dam, Jos Marcus,

23. Liesbeth Perdeck and Keith Medhurst (2012) Organisation and management an international approach. 2nd edition. The Netherlands: Nordhoff Uitgevers bv Groninton/Houten.

24. Okafor Obiefuna A. (2014) "The role of top management in business organizations", Review of Public Administration and Management, 3 (5), 93-105.

25. Peng-Yu Li (2018) "Top management team characteristics and firm internationalization: the moderating role of the size of middle managers", International Business Review, 27, 125-138.

26. Pinto, J. K. and Slevin, D. P. (1988) "Critical success factors across the project life cycle: definitions and measurement techniques”, Project Management Journal, 19(3), 67-75.

27. PMI (2017) A guide to the project management body of knowledge. 5th edition. Pennsylvania: Project Management Institute Inc.

28. Radujković, Mladen and Sjekavica, Mariela (2017) "Project Management Success Factors", Procedia Engineering, 196, 607 - 615.

29. Raymond Young and Simon Poon (2013) "Top management support-almost always necessary and sometimes sufficient for success: findings from a fuzzy set analysis", International Journal of Project Management, 31, 943-957.

30. Reza Kiani Mavi and Standing, Craig (2018) "Cause and effect analysis of business intelligence (BI) benefits with fuzzy DEMATEL", Knowledge Management Research \& Practice, 16(2), 245-257.

31. Riaz Ahmed (2015) The Moderating Role of Top Management Support on the Relationship between Project Manager's Leadership Competencies and Project Success. PhD Thesis, Universiti Teknologi Malaysia, Skudai.

32. Riaz Ahmed, Noor Azmi Bin Mohamad and Muhammad Shakil Ahmad (2016) "Effect of multidimensional top management support on project success: an empirical investigation", Springer Science+Business Media Dordrecht, 50, 151-176.

33. Richard M. Hodgetts and Donald F. Kuratko Hodgetts (2001) Effective small business management. 7th edition. New York: John Wiley \& Sons.

34. Rupak Rauniar and Greg Rawski (2012) "Organizational structuring and project team structuring in integrated product development project", International Journal of Production Economics, 135(2), 939-952.

35. Sebestyen Zoltan (2017) "Further considerations in project success", Procedia Engineering, 196, 571 - 577.

36. Shenhar, A., Dvir, D., Levy, O. and Maltz, A.A.C. (2001) "Project success: a multidimensional strategic concept", Long Range Plan, 34 (6), 699-725.

37. Stephen J. Skripak (2016) Fundamentals of business. 1st edition. Virginia: Virginia Tech University Libraries.

38. Sumesh Sudheer Babu and Sudhaka (2015) "Critical Success factors influencing performance of construction projects", International Journal of Innovative Research in Science, Engineering and Technology, 4(5), 3285-3292.

39. Turner, J.R. (2009) The handbook of project-based management. 3rd edition. New York: McGraw Hill.

40. Yap Eng Hoe (2013) Causes of Abandoned Construction Projects in Malaysia. Master Thesis, Universiti Tunku Abdul Rahman, Kuala Lumpur.

41. Yong, Yee Cheong and Nur Emma Mustaffa (2017) "Critical success factors for Malaysian construction projects: an investigative review", International Journal of Built Environment and Sustainability, 4(2), 93-104.

42. Young, Raymond and Poon, Simon K. (2013) “Top management support-almost always necessary and sometimes sufficient for success: findings from a fuzzy set analysis", Journal of Project Management, 31(7), 943-957.

43. Zairi, M. (1997) "Business process management: a boundaryless approach to modern competitiveness", Business Process Management Journal, 3 (1), 64-80.

\section{AUTHORS PROFILE}

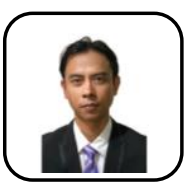

First Author Muhammad Hafizi Danial possesses an Honours Bachelor Degree of Civil and Structural Engineering from Universiti Kebangsaan Malaysia and First Class Master Degree in Project Management from Universiti Teknologi Malaysia. He is a professional engineer registered with Board of Engineers Malaysia (BEM) and currently holding a position as a Construction Manager in an Offshore Construction Company in Malaysia. Currently, he is pursuing a Project Management Professional certification from Project Management Institute (PMI). His main specialization are in Project Management and Strategic Management areas. This technical paper titled "Critical Strategies to Influence Project Success in Construction Industry" is his first ever publication with any International Journal Publication House.

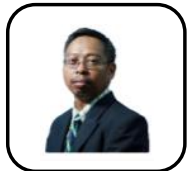

Second Author Mohd Saidin Misnan was graduated with Quantity Surveying Degree from Universiti Teknologi Malaysia, MSc. (Project Management) from Universiti Sains Malaysia and obtained his PhD (Facilities Management) from Universiti Teknologi Malaysia. Currently, he is an Associate Professor in the Department of Quantity Surveying, Faculty of Built Environment and Surveying, Universiti Teknologi Malaysia. He has 25 years of experience as an academician, especially lecturing in Construction Technology. He is a Consultant Quantity Surveyor (CQS), Member Royal Institutions of Surveyor, Malaysia (RISM), Professional Surveyor, Chartered Surveyor, Royal Institution of Chartered Surveyor (RICS, UK), Member, The Chartered Institute of Building, United Kingdom (CIOB), and Member, Institute of Value Management, Malaysia (IVMM). He has published around 43 numbers of Journals and Proceedings mainly in safety practice and construction management. This paper is his $44^{\text {th }}$ submission to the International Journal Publisher. 